\title{
Pengembangan Model Pembelajaran Problem-Map Untuk Mengembang- kan Sikap Pelestarian Lingkungan Hidup Mahasiswa IKIP Budi Utomo Malang
}

\author{
Erfitra Rezqi Prasmala \\ Program Studi Pendidikan Biologi IKIP Budi Utomo Malang \\ Jalan Citandui 46 Malang \\ e-mail:dphitlah@yahoo.co.id \\ Dyah Ayu Widya Ningrum \\ Program Studi Pendidikan Biologi IKIP Budi Utomo Malang \\ Jalan Citandui 46 Malang \\ Dwi Candra Setiawan \\ Program Studi Pendidikan Biologi IKIP Budi Utomo Malang \\ Jalan Citandui 46 Malang
}

\begin{abstract}
In the midst of technological development and increasing need to encourage people to large exploitation of environment, resulting in demage and environmental pollution. Humans is natural destroyer agent, in an efforto preserve the environment need to developed conceptual continuously. Based on observations, shows that students still have the attitude of environmental conservation is low. Design of learning not to lead to the settlement solving in the enviroment arounda the student, so that a low sense love for the environment and fostering poor attitude of environmental conservation. he learning model is applied to improve the condition is Problem-Map. This learning model implemented in several stages: (1) Problem Based Learning and (2) Making the Mind Map in solving problems. This research will develop learning model Problem-Map, the development of research methods using models Borg and Gall (1983). Based on trial results through the activities of PTK learning model suggests that the model of teaching Problem-Map can developing attitude of environmental conservation students at IKIP Budi Utomo Malang
\end{abstract}

Keywords: Problem Based Learning, mind map, attitude of environmental conservation

Semakin berkembangnya budaya dan teknologi di Indonesia, menuntut manusia untuk terus melakukan eksploitasi secara besarbesaran terhadap lingkungan sesuai dengan keinginan dan tuntutan kebutuhannya. Hal ini secara tidak langsung dapat mempengaruhi keseimbangan dan kelestarian unsur-unsur dalam lingkungan. Ketidakseimbangan ini bahkan sekarang ini menyebabkan berbagai pencemaran dan kerusakan lingkungan, sehingga manusia seringkali dianggap sebagai agen perusak alam. Sebagai upaya dalam menjaga kelestarian lingkungan hidup, perlu dilakukan pembinaan yang konseptual secara terus menerus. Pembinaan dilakukan untuk pembinaan sikap positif terhadap lingkungan melalui pendidikan, seperti yang dilakukan pada pembelajaran di matakuliah pengetahuan lingkungan. Pengetahuan lingkungan merupakan salah satu mata kuliah yang diajarkan pada mahasiswa di IKIP Budi Utomo Malang. Mata kuliah ini merupakan wahana untuk meningkatkan pengetahuan, keterampilan, sikap dan nilai serta tanggung jawab sebagai seorang warga negara yang bertanggung jawab kepada lingkungan, masyarakat, bangsa dan negara.

Berdasarkan hasil observasi selama pembelajaran Biologi di IKIP Budi Utomo Malang pada tahun 2014 menunjukkan rendahnya kepedulian mahasiswa terhadap lingkungan, hal ini terlihat dengan berbagai sikap mahasiswa yang seringkali membuang sampah sembarangan, merokok disekitaran kampus yang juga akan menyumbang pencemaran udara dan belum ada rasa cinta untuk terus melestarikan serta menjaga kondisi lingkungan disekitar 
mereka. Sebagai seorang pendidik, kenyataan rendahnya kepeduliaan lingkungan tentu mengundang keprihatinan yang dalam, sebab melalui mata kulia ini mahasiswa seharusnya melakukan tindakan-tindakan positif terhadap lingkungan hidup seperti yang dibinakan selama perkuliahan. Melalui matakuliah pengetahuan lingkungan seharusnya selama pembelajaran dosen harus mengarahkan mahasiswa memiliki sikap pelestarian lingkungan hidup. Mahasiswa seharusnya memiliki kecintaan terhadap alam, serta memiliki keinginan untuk menjaga serta menyelesaikan berbagai permasalahan yang ada di lingkungan sekitar mahasiswa. Proses pembelajaran yang kurang mengaitkan dengan permasalahan-permasalahan lingkungan disekitar mereka, merupakan salah satu hal yang menjadi permasalahannya.

Sikap pelestarian lingkungan hidup mahasiswa yang rendah ini disebabkan oleh kemampuan berpikir mahasiswa yang kurang diberdayakan untuk dapat menganalisis terhadap berbagai masalah yang ada disekitar mahasiswa. Berdasaran hasil observasi pada tahu 2014 menunjukkam selama pembelajaran kegiatan hanya berupa presentasi dengan melakukan pembahasan berdasarkan kajiankajian teoritis, dosen jarang meminta mahasiswa untuk melakukan analisis, sehingga berdampak pada rendahnya hasil belajar mahasiswa. Hal ini terlihat sekita $40 \%$ mahasiswa mendapat nilai D. Rendahnya kemampuan berpikir mahasiswa menganai lingkungan ini, juga diikuti dengan kenyataan bahwa masih rendahnya pula kepedulian terhadap lingkungan. Hal ini terlihat dengan berbagai sikap, misalnya mahasiswa membuang sampah secara sembarangan, merokok yang merupakan penyumbang dalam pencemaran udara, dan kerusakan-kerusakan lingkungan yang belakangan ini terjadi di Indonesia (Mahasiswa IKIP Budi Utomo berasal dari berbagai tempat di Indonesia).

Sebagai seorang pendidik, kenyataan rendahnya kepeduliaan lingkungan tentu mengundang keprihatinan yang dalam, sebab melalui mata kulia ini mahasiswa seharusnya melakukan tindakan-tindakan positif terhadap lingkungan hidup seperti yang dibinakan selama perkuliahan. Melalui matakuliah pengetahuan lingkungan seharusnya selama pembelajaran dosen harus mengarahkan mahasiswa memiliki sikap pelestarian lingkungan hidup. Mahasiswa seharusnya memiliki kecintaan terhadap alam, serta memiliki keinginan untuk menjaga serta menyelesaikan berbagai permasalahan yang ada di lingkungan sekitar mahasiswa. Proses pembelajaran yang kurang mengaitkan dengan permasalahan-permasalahan lingkungan disekitar mereka, merupakan salah satu hal yang menjadi permasalahannya.

Berdasarkan hal tersebut, mendorong peneliti untuk melakukan penelititian dalam meningkatkan sikap pelestarian lingkungan hidup. Penanaman sikap pelestarian lingkungan hidup tidak terlepas dengan tingkat pengetahuan mahasiswa. Hal ini sesuai dengan penelitian yang dilakukan oleh Nurfiana (2005) yang menyimpulkan bahwa pengetahuan mempengaruhi sikap peduli terhadap lingkungan hidup, sehinggadengan pengetahuanyangcukup diharapkan dapat menumbuhkan kesadaran untuk melestarikan lingkungan. Nikmah (2007) menyimpulkan ada pengaruh penerapan materi lingkungan hidup dan pembangunan berwawasan lingkungan terhadap sikap dan perilaku siswa kelas XI MAN Malang 1 pada pelestarian lingkungan. Berdasarkan penelitianpenelitian terdahulu menunjukkan untuk meningkatkan sikap pelestarian lingkungan hidup, perlu ada pemberdayaan kemampuan berpikir mahasiswa sehingga meningkatkan pengetahuan mahasiswa.

Sebagai upaya untuk mengatasi berbagai masalah di atas, peneliti mengusulkan pengembangan pembelajaran dengan menggunakan model Problem-Map. Model pembelajaran ini pada awal pembelajaran dosen melakukan pembelajaran berbasis Problem Based Learning (PBL) yaitu metode pembelajaran yang mampu membelajarkan siswa untuk lebih peka dengan lingkungan sekitar. PBL merupakan metode pembelajaran yang berasosiasi dengan pendekatan konstekstual. Jadi subjek kajian dalam ilmu Biologi adalah alam itu sendiri. Penerapan metode pembelajaran tersebut akan membuat siswa lebih aktif dalam proses pembelajarannya (Nurhadi, Senduk Gerrad., 2004). Pembelajaran PBL akan membelajarkan mahasiswa dengan menunjukkan berbagai masalah-masalah yang ada di lingkungan mereka, dan mahasiswa akan merumuskan berbagai usulan penyelesaian untuk mengatasi berbagai permasalahan lingkungan. Melalui metode PBL mahasiswa lebih aktif dalam pembelajaran dan mampu memecahkan masalah terutama masalah yang ditemukan dalam kehidupan sehari-hari. Selama pemecahan masalah kemampuan berpikir mahasiswa sangat diberdayakan dengan mengaitkan berbagai pengetahuan yang mereka miliki menjadi satu konsep yang dapat dipakai untuk memecahkan masalah. Melalui perkuliahan pengetahuan 
lingkungan dengan model ini akan terbentuk kesadaran dan kepekaan siswa terhadap masalah di lingkungan sekitar dan akan mempermudah mahasiswa untuk mempelajari dan memahami konsep Pengetahuan Lingkungan sehingga dapat memberdayakan kemampuan berpikir mahasiswa.

Selama proses pemecahan masalah, mahasiswa akan kesulitan dalam merumuskan penyelesaian yang akan diusulkan. Dalam merumuskan penyelesaian dosen mengarahkan mahasiswadenganmembuatMind Mapsehingga mahasiswa akan mudah dalam menyusun cara penyelesaian dengan mudah dan mengaitkan dengan berbagai konsep yang telah mereka ketahui. Buzan (2004) menyebutkan bahwa mind map merupakan teknik yang paling baik dalam membantu proses berfikir oleh otak secara teratur karena menggunakan teknik grafis yang berasal dari pemikiran manusia yang bermanfaat untuk menyediakan kunci-kunci universal sehingga membuka potensi otak. Menurut Gunawan (2003), teknik mencatat berupa mind map didasari hasil riset bahwa cara otak mengolah informasi tidak secara linier, setahap demi setahap tetapi otak menyimpan informasi dan memproses informasi secara acak. Di samping itu, otak menyimpan informasi dalam bentuk gambar dan bukan dalam bentuk huruf atau tulisan.

Berdasarkan uraian di atas, maka dilakukan penelitian mengenai pengembangan model pembelajaran Problem-Map untuk memberdayakan kemampuan berpikir dan sikap pelestarian lingkungan pada mahasiswa IKIP Budi Utomo Malang.

\section{METODE}

Metode penelitian ini adalah pengembangan menggunakan model Borg and Gall (1983) yang terdiri dari 10 tahap, yaitu: (1) Research and information collecting dilakukan dengan melakukan observasi awal pembelajaran dan menemukan data-data pra penelitian mengenai hasilbelajar,kemampuanberpikirkritis, dansikap pelestarian lingkungan hidup (2) Planning yang dilakukan pada tahap ini adalah perencanaan penyusunan sintask model pembelajaran berdasarkan hasil kajian pada langkah pertama (3) Develop preliminary form of product, pada tahap ini dilakukan pengembangan sintaks pembelajaran beserta perangkat pembelajaran, yang terdiri dari RPS, RPPS, dan Lembar Kerja Mahasiswa sesuai dengan model Problem-Map
(4) Preliminary field testing, dilakukan dengan uji validasi oleh 3 orang validator yang teridri dar 1 orang dosen pakar pembelajaran pengetahuan lingkungan dan 2 orang dosen yang mengampuh matakuliah pengetahuan lingkungan (5) Main product revision, dilakukan dengan melakukan revisi berdasarkan masukan dari para validator (6) Main field testing, (7) Operational product revision, (8) Operational field testing, (9) Final product revision.

Tahapan 6-9 dilakukan melalui Penelitian Tindakan Kelas (PTK) Pada-siklus pertama PTK, akan dilakukan uji coba lapang awal (main field testing) atau pengkajian sintaks model pembelajaran dan perangkat yang telah disusun. Hasil refleksi PTK siklus pertama, akan digunakan untuk melakukan revisi (operational productrevision). Hasil revisi tersebut kemudian digunakan lagi pada PTK siklus kedua (operational field testing). Berdasarkan hasil refleksi pada PTK siklus kedua, akan dilakukan revisi kembali (final product revision). Variabel pemberdayaan berpikir yang akan diukur pada peneliian ini (1) kemampuan berpikir kritis, (2) hasil belajar kognitif, dan (3) sikap pelestarian lingkungan hidup. Pada akhirnya, model ini mampu memberdayakan kemampuan berpikir dan mampu meningkatkan sikap pelestarian lingkungan hidup mahasiswa di Budi Utomo Malang.

Subjek penelitian Mahasiswa Kelas G 2013 IKIP budi Utomo Malang dengan jumlah siswa 43 orang yang terdiri dari 24 siswa laki-laki dan 19 siswa perempuan, dengan kemampuan akademik mahasiswa yang heterogen. Instrumen yang digunakan dalam penelitian ini berupa angket skala sikap terhadap pelestarian, soal tes akhir siklus yang dinilai dengan menggunakan rubrik kemampuan berpikir kritis dan hasil belajar mahasiswa.

\section{HASIL}

Pengembangan model pembelajaran dilakukan melalui tahapan a) Research and information collecting, sehingga didapat data awal mahasiswa mengenai kemampuan berpikir mahasiswa yang rendah yang ditunjukkan dengan $40 \%$ mahasiswa tidak lulus mengikuti perkuliahan pengetahuan lingkungan. Data angket sikap pelestarian lingkungan mahasiswa yang rendah dengan 51,16\% mahasiswa dalam kategori cukup baik, 46, 51\% mahasiswa dalam kategorikurangbaikdan2,32\% mahasiswadalam kategori kurang sekali. Untuk merumuskan 
model pembelajaran ini ada beberapa hasil penelitian yang dirujuk sebagai dasar teori salah satunya adalah Penerapan Problem Based Learning dan Inkuiri untuk meningkatkan kemampuan berpikir kritis dan sikap kepedulian lingkungan mahasiswa fakultas kesehatan masyarakat Universitas Muhammadiyah Aceh (Anwar., dkk. 2014), Model Pembelajaran Problem Solving dengan Mind Mapping terhadap kemampuan berpikir kritis siswa (Ristiasari, Tia., dkk. 2012) dan lain sebagainya.

Pada tahap Planning telah direncanakan model pembelajaran Problem-Map dengan sintaks pembelajaran seperti pada Tabel 1. Sintaks disusun berdasarkan teori-teori yang mendukung yaitu tentangProblem Based Learning (Pembelajaran Berbasis Masalah)dan
Pembelajaran berbasis Mind Map (Peta Konsep). Mengacurumusan dari Dutch (1994) menyatakan bahwa PBL merupakan metode instruksional yang menantang peserta didik agar belajar untuk belajar, bekerjasama dalam kelompok untuk mencari solusi bagi masalah yang nyata. Masalah digunakan untuk mengaitkan rasa keingintahuan serta kemampuan analisis peserta didik dan inisiatif atas materi pelajaran. PBL akan mempersiapkan peserta didik untuk berpikir kritis dan analitis dan untuk mencari serta menggunakan sumber pembelajaran yang sesuai. Pembelajaran berbasis masalah bertujuan untuk mencapai kemampuan siswa utuk berpikir kritis, analitis, sistematid, dan logis dalam menemukan alternatif pemecahan masalah melalui eksplorasi data secara empiris dalam rangka menumbuhkan sikap ilmiah.

Tabel 1. Sintaks Pembelajaran Model Problem-Map

\begin{tabular}{|c|c|c|}
\hline Sintaks & & Kegiatan Pembelajaran \\
\hline Tahap I & $\begin{array}{l}\text { Orientasi siswa kepada } \\
\text { masalah }\end{array}$ & $\begin{array}{l}\text { Dosen menjelaskan tujuan pembelajaran, } \\
\text { menjelaskan logistik yang dibutuhkan, } \\
\text { memotivasi siswa agar terlibat pada } \\
\text { aktivitas pemecahan masalah yang } \\
\text { dipilhnya dan menunjukkan beberapa } \\
\text { fenomena yang terjadi dilingkungan sekitar } \\
\text { mahasiswa yang merupakan masalah } \\
\text { yang harus dipecahkan oleh mahasiswa }\end{array}$ \\
\hline Tahap II & $\begin{array}{l}\text { Mengorganisasi siswa untuk } \\
\text { belajar }\end{array}$ & $\begin{array}{l}\text { Dosen membantu peserta didik } \\
\text { mendefinisikan dan mengorganisasikan } \\
\text { tugas belajar yang berhubungan dengan } \\
\text { masalah tersebut. }\end{array}$ \\
\hline Tahap III & $\begin{array}{l}\text { Membimbing penyelidikan } \\
\text { individual dan kelompok } \\
\text { Mind Map }\end{array}$ & $\begin{array}{l}\text { Dosen mendorong siswa untuk } \\
\text { mengumpulkan informasi yang seuai, } \\
\text { melaksanakan eksperimen, untuk } \\
\text { mendapatkan penjelasan dan pemecahan } \\
\text { masalahnya. } \\
\text { Dalam memecahkan masalah siswa } \\
\text { mengembangkan kerangka berpikir tentang } \\
\text { pemecahannya dalam bentuk mind map }\end{array}$ \\
\hline Tahap IV & $\begin{array}{l}\text { Mengembangkan dan } \\
\text { menyajikan hasil karya }\end{array}$ & $\begin{array}{l}\text { Dosen membantu peserta disik memecahkan } \\
\text { dan menyiapkan karya yang sesuai seperti } \\
\text { laporan video dan model serta membantu } \\
\text { mereka berbagi tugas dengan temannya. }\end{array}$ \\
\hline Tahap V & $\begin{array}{l}\text { Menganalisis dan } \\
\text { mengevaluasi proses } \\
\text { pemecahan masalah }\end{array}$ & $\begin{array}{l}\text { Dosen membantu peserta didik melakukan } \\
\text { refleksi/ evaluasi terhadap penyelidikan } \\
\text { mereka dan proses-proses yang mereka } \\
\text { gunakan. }\end{array}$ \\
\hline
\end{tabular}


Masalah-masalah yang disajikan dalam PBL diharapkan dapat mendorong siswa untuk menemukan bagaimana cara memecahkan suatu permasalahan. Pemikiran dengan menampilkan berbagai masalah tersebut akan menimbulkan pemikiran siswa untuk senantiasa mencari sumber informasi lebih banyak untuk menemukan solusi dalam memcahkan permasalahan.

Mata kuliah pengetahuan lingkungan merupakan matakuliah wajib yang harus diampuh oleh mahasiswa IKIP Budi Utomo Malang. Matakuliah ini akan mengajarkan tentang konsep lingkungan, isu lingkungan, dan pengelolahannya. Melalui matakuliah ini diharapkan mahasiswa mampu memahami konsep dasar lingkungan hidup, menganalisis permasalahan lingkungan yang ada disekitar mahasoswa dan dalam skala global, nasional, dan lokal, serta mampu menghubungkan kegiatan manusia dengan potensi, prospek, dan strategi pemanfaatan SDA dan lingkungan secara berkesinambungan.

Mata kuliah ini merupakan wahana untuk meningkatkan pengetahuan, keterampilam, sikap dan nilai serta tanggung jawab sebagai seorang warga negara yang bertanggung jawab kepada lingkungan, masyarakat, bangsa dan negara. Pembelajaran dalam matakuliah pengetahuan lingkungan merupakan sarana dalam pembinaan pelestarian lingkungan pada mahasiswa, jadi matakuliah ini bisa menumbuhkan rasa cinta terhadap lingkungan. Model pembelajaran Problem Based Learning pada matakuliah pengetahuanlingkungan merupakan upaya pembinaan kesadaran terhadap manfaat pelestarianlingkunganhidup, melaluimodelPBL peserta didik akan mengkonstruk pengetahuan secara mandiri sehingga dari kegiatan tersebut siswa merasa peduli terhadap lingkungan, yang akhirnya dapat membentuk sikap dan perilaku positif terhadap lingkungan hidup.

Pada setiap langkah dalam pembelajaran PBL dapat menumbuhkan rasa ingin tahu siswa tentang lingkungannya, PBL akan membuka wawasan peserta didik tentang alam sekitar karena masalah yang dimunculkan untuk mengawali proses pembelajaran adalah masalah yang ada disekitar siswa. Dalam hal ini siswa merasa belajar itu bukan hanya sekedar mengetahui tentang teori tetapi peserta didik akan berperan sebagai pencari solusi dari masalah yang terjadi di sekitar.

Salah satu teknik yang dapat digunakan untuk mengingat dan mengolah informasi menurut DePorter dan Hernacki (1999) yaitu pemetaan pikiran (mind mapping). Teknik ini merupakan cara yang paling mudah untuk memasukan informasi ke dalam otak dan untuk kembali mengambil informasi dari dalam otak. Buzan (2004) menyebutkan bahwa mind map merupakan teknik yang paling baik dalam membantu proses berfikir oleh otak secara teratur karena menggunakan teknik grafis yang berasal dari pemikiran manusia yang bermanfaat untuk menyediakan kunci-kunci universal sehingga membuka potensi otak.

Menurut Gunawan (2003), teknik mencatat berupa mind map didasari hasil riset bahwa cara otak mengolah informasi tidak secara linier, setahap demi setahap tetapi otak menyimpan informasi dan memproses informasi secara acak. Di samping itu, otak menyimpan informasi dalam bentuk gambar dan bukan dalam bentuk huruf atau tulisan. Sehingga kelebihan mind map adalah dapat menirukan proses berpikir yakni memungkinkan siswa untuk berpindah-pindah topik. Selain itu, mind map merekam informasi melalui simbol, gambar, arti emosional, dan dengan warna, persis seperti cara otak memprosesnya. Karena mind map melibatkan kedua belah otak, informasi akan dapat diingat dengan mudah (DePorter dkk, 2000).

Tahap selanjutnya adalah Develop preliminary form of product, pada tahap ini telah disusun sintaks model pembelajaran kedalam RPS, RPPS, dan lembar kerja mahasiswa. Tahap selanjutnya adalah Preliminary field testing yang dilakukan dengan melakukan validasi oleh validator ahli yaitu Dra.Hawa Tuarita M.S, yang merupakan dosen Ekologi Lingkungan di Universitas Negeri Malang, dan validator dari dosen pengampuh matakuliah Pengetahuan Lingkungan yaitu Selvi Ariyunita S.Si, M.Si dan Ika Oktaviana, S.Si, M.Pd. Hasil dari validator menyatakan bahwa RPS dan RPPS sudah layak untuk dipakai, akan tetapi perlu ada beberapa revisi.

Tahap selanjutnya adalah tahap Main product revision dilakukan dengan melakukan revisi pada perangkat pembelajaran yang terlah divalidasi oleh validator, beberapa masukan dari validator adalah a) Bahan air yang dipakai untuk mengukur kadar bahan pencemar di dapat dari air yang memang bermanfaat bagi masyarakat, misalnya diambil dari air sungai yang sering dimanfaatkan manusia, b) perlu ada pengurutan materi sehingga mempermudah materi bagi mahasiswa, c) kesalahan pengetikan perlu diperbaiki, d) Tidak perlu ada pertanyaan yang menuntun dalam menganalisis, 
mahasiswa dimungkinkan bisa untu menganalisis masalah. Hasil masukan dari beberapa validator ini akan dipakai sebagai revisi perangkat pembelajaran.

Pada tahap Main field testing dilakukan uji coba lapangan awal atau dengan pengkajian sintaks model pembelajaran dan perangkat yang telah melalui siklus I dalam PTK (Penelitian Tindakan Kelas) yang dilakukan di jurusan Matematika pada matakuliah pengetahuan lingkungan karena pada semester ini matakuliah pengetahuan lingkungan di Biologi tidak ada. Matakuliah pengetahuan lingkungan memiliki kesamaan capaian komptensi dengan kurikulum pada Pendidikan Biologi. Hasil refleksi dari siklus I ini akan dipakai pada tahapan Operational Product Revision dalam menghasilkan perangkat pembelajara pada siklus II. Setelah pelaksanaan penelitian pada siklus II didapatkan hasil penelitian pada tahap Operational field testing yang didapatkan hasil yang menunjukkan bahwa model pembelajaran Problem Map dapat meningkatkan sikap pelestarian lingkungan hidup.

Penerapan model Problem-Map mampu meningkatkan sikap pelestarian lingkungan hidup. Berdasarkan hasil observasi melalui angket menunjukkan adanya peningkatan sikap pelestarian lingkungan hidup mahasiswa pada siklus I sebesar 51,67\% dengan kategori cukup baik dan mengalami peningkatan pada siklus II menjadi 71,02\% dengan kategori baik, terjadi peningkatan sebesar $19,35 \%$. Secara rinci distribusi frekuensi kategori sikap pelestarian lingkungan hidup mahasiswa IKIP Budi Utomo Malang dapat dilihat pada Tabel 1. oleh mahasiswa yang bisa digunakan sebagai saran mengkonstruk pengetahuan dan mengevaluasi perolehan pengetahuan yang dimiliki oleh mahasiswa. Jadi berdasarkan hasil pengembangan penelitian ini menunjukkan bahwa model pembelajaran Problem-Map mampu mengembangkan kemampuan berpikir dan sikap pelestarian lingkungan hidup mahasiswa IKIP Budi Utomo Malang.

\section{PEMBAHASAN}

Pengembangansikap pelestarian lingkungan harus dimulai sejak dini. Pembinaan ini dapat dilakukan melalui pendidikan formal (SD sampai Perguruan Tinggi) maupun nonformal misalnya melalui keluarga, kegiatan-kegiatan dalam masyarakat dan media komunikasi (cetak, elektronik). Agar sikap peduli terhadap lingkungan akan lama bertahan dalam diri siswa. Menurut Walgito (1999) jika suatu sikap telah terbentuk dan merupakan nilai dalam kehidupan seseorang, secara relatif sikap itu akan lama bertahan pada diri orang tersebut. Sikap tersebut akan sulit berubah, dan jika berubah akan membutuhkan waktu yang relatif lama. Begitu sebaliknya jika sikap itu belum begitu mendalam dalam diri seseorang, maka sikap secara relatif tidak bertahan lama dan mudah berubah.

Model Pembelajaran Problem-Map merupakan model pembelajaran yang pada awal pembelajaran pembelajaran dilakukan dengan menggunakan model Problem Based Learning (PBL) dan

Tabel 1. Peningkatan Frekuensi Sikap Pelestarian Lingkungan Hidup Mahasiswa

\begin{tabular}{lcccc}
\hline \multirow{2}{*}{ Kategori } & \multicolumn{2}{c}{ Siklus I } & \multicolumn{2}{c}{ Siklus II } \\
\cline { 2 - 5 } & Frek & \% & Frek & $\%$ \\
\hline SangatBaik & 0 & 0 & 1 & 0 \\
Baik & 5 & 11,62 & 19 & 44,186 \\
Cukup baik & 17 & 39,53 & 18 & 41,86 \\
Kurang & 21 & 48,8372093 & 5 & 11,62 \\
Kurang Sekali & 0 & 0 & 0 & 0 \\
\hline Jumlah & 43 & 100 & 43 & 100 \\
\hline
\end{tabular}

Tahap akhir yang dilakukan pada penelitian pengembangan ini adalah Final product revision yang dilakukan revisi kembali pada siklus II berdasarkan hasil refleksi pada siklus II, ada beberapa hal yang perlu ada perbaikan berdasarkan hasil refleksi yaitu Penggunaan Mind Map sangat perlu terus dikembangkan merumuskan penyelesaian dosen mengarahkan mahasiswa dengan membuat Mind Map sehingga mahasiswa akan mudah dalam menyusun cara penyelesaian dengan mudah dan mengaitkan dengan berbagai konsep yang telah mereka ketahui. PBL merupakan model pembelajaran yang akan membelajarkan mahasiswa untuk 
lebih peka dengan lingkungan sekitar dan berasosiasi dengan pendekatan kontekstual.

Pembelajaran PBL akan membelajarkan mahasiswa dengan menunjukkan berbagai masalah-masalah yang ada dilingkungan mereka, dan mahasiswa akan merumuskan berbagai usulan penyelesaian untuk mengatasi berbagai permasalahan lingkungan. Perkuliahan pengetahuan lingkungan dengan model PBL akan membentuk kesadaran dan kepekaan mahasiswa terhadap berbagai masalah di lingkungan sekitar mahasiswa. Sikap pelestarian lingkungan hidup perlu terus dikembangkan secara terus menerus, sehingga timbul rasa cinta pada lingkungan. Pembinaan secara terus menerus perlu dilakukan, matakuliah pengetahuan lingkungan akan mengajarkan mahasiswa memahami konsep dasar lingkungan hidup, menganalisis permasalahan lingkungan yang ada disekitar mahasiswa dan dalam skala global, nasional, dan lokal, serta mampu menghubungkan kegiatan manusia dengan potensi, prospek, dan strategi pemanfaatan SDA dan lingkungan secara berkesinambungan. Pengetahuan lingkungan merupakan mata kuliah yang bertujuan untuk meningkatkan pengetahuan, keterampilan, sikap, dan nilai serta tanggung jawab sehingga mampu menciptakan mahasiswa yang bertanggungjawab kepada lingkungan, masyarakat, bangsa, dan negara.

Selamaperkuliahan pengetahuanlingkungan dosen selalu mengarahkan mahasiswa untuk memiliki sikap pelestarian lingkungan dan rasa kecintaan terhadap alam, serta memiliki keinginan untuk menjaga serta menyelesaikan berbagai permasalahan yang ada di lingkungan sekitar mahasiswa. Pembelajaran dengan model PBL selalu dimulai dengan mengaitkan berbagai masalah yang sedang terjadi di Indonesia, mahasiswa akan terus berupaya menuliskan berbagai cara yang bisa dilakukan ataupun bisa diusulkan ke pemerintah untuk mengatasis berbagai masalah tersebut.

Mahasiswa akan menggali pengetahuan mereka mengenai pengetahuan lingkungan dan mampu merumuskan penyelesaikan yang akan diusulkan. Penanaman sikap pelestarian lingkungan hidup melalui matakuliah pengetahuan lingkungan hidup ini dirasa sangat sesuai. Hal ini sesuai dengan penelitian yang dilakukan oleh Nurfiana (2005) yang menyimpulkan bahwa pengetahuan mempengaruhi sikap peduli terhadap lingkungan hidup, sehingga dengan pengetahuan yang cukup diharapkan dapat menumbuhkan kesa- daran untuk melestarikan lingkungan. PBL dapat meningkatkan sikap siswa yang positif, pengalamanobservasi lapangan untuk melihat secara langsung permasalahan lingkungan sekitar dapat meningkatkan sikap peduli siswa terhadap lingkungannya (Husna, 2013).

Penggunaan Mind map selama perumusan masalah akan memudahkan mahasiswa dalam menyusun cara penyelesaian dengan mudah dan mengaitkan dengan berbagai konsep yang telah mereka ketahui. Buzan (2004) menyebutkan bahwa mind map merupakan teknik yang paling baik dalam membantu proses berfikir oleh otak secara teratur karena menggunakan teknik grafis yang berasal dari pemikiran manusia yang bermanfaat untuk menyediakan kunci-kunci universal sehingga membuka potensi otak. Menurut Gunawan (2003), teknik mencatat berupa mind map didasari hasil riset bahwa cara otak mengolah informasi tidak secara linier, setahap demi setahap tetapi otak menyimpan informasi dan memproses informasi secara acak. Di samping itu, otak menyimpan informasi dalam bentuk gambar dan bukan dalam bentuk huruf atau tulisan. Berdasarkan pemaparan di atas, maka dapat disimpulkan bahwa penerapan model pembelajaran ProblemMap dapat mengembangkan sikap pelestarian lingkungan mahasiswa.

\section{KESIMPULAN DAN SARAN}

Berdasarkan paparan data dan pembahasan yang telah diuraikan dapat diambil kesimpulan bahwa model Problem-Map dapat mengembangkan sikap pelestarian lingkungan mahasiswa IKIP Budi Utomo Malang. Hal ini ditunjukkan adanya peningkatan sikap pelestarian lingkungan hidup mahasiswa pada siklus I sebesar 51,67\% dengan kategori cukup baik dan mengalami peningkatan pada siklus II menjadi 71,02\% dengan kategori baik, terjadi peningkatan sebesar $19,35 \%$.

Disarankan dalam merumuskan masalah pada mahasiswa, di cari masalah-masalah yang up to date, sehingga mahasiswa benarbenar mencoba terlibat dalam menyelesaikan masalahnya dan lebih bermakna bagi mahasiswa. Melihat potensi dari model ini disarankan agar dalam pembelajaran dengan model ini dapat diaplikasikan khususnya pada mata kuliah pengetahuan lingkungan, sehingga sikap pelestarian lingkungan mahasiswa terus terbina dan tertanam bagi mahasiswa. 